\title{
Maternal identity for Orthodox Jewish couples using donor oocytes or surrogacy is not well established
}

\author{
Joel B. Wolowelsky ${ }^{1,2} \cdot$ Richard V. Grazi ${ }^{1,2}$ \\ Received: 27 February 2020 / Accepted: 24 March 2020 / Published online: 2 April 2020 \\ (C) Springer Science+Business Media, LLC, part of Springer Nature 2020
}

To the Editor:

Good counseling for infertile couples considering ART should understand the individual and community values of the patients. It must anticipate and address future issues that the couple might encounter, and that requires up-to-date authoritative information. Those relying on the recent conclusion in these pages [1] that Judaism grants maternity to the woman in whose womb the fetus gestates may find the Jewish status of their children is not fully accepted, and they are therefore unable to freely marry within the traditional Jewish community.

Halakha is the corpus of traditional Jewish religious law and ethics. While there are basic universally accepted foundation legal texts, there is no hierarchy of rabbinic court's ruling on halakhic issues. Well-respected halakhic authorities publish legal opinions (called responsa) for informal peer review. As a matter of course, it often happens that one position becomes dominant. Decades ago, when the issue began to emerge, it seemed that the dominant position was that the gestational mother was viewed as the halakhic mother. Such a position was championed by such leading authorities as the former Chief Rabbis of Israel, Shlomo Goren, and Mordechai Eliyahu. Over the years, however, the contrasting position that it is the genetic mother who is the halakhic mother has gained traction, proposed by such authorities as the former Chief Rabbis of Israel Ovadia Yosef and Moshe Amar. No consensus has emerged. [2]

The halakhic Jewish status of a child is inherited exclusively from his or her halakhic mother, whether or not the father is Jewish. Thus, in the cases of donor eggs or surrogacy, if one

Joel B. Wolowelsky

wolowelsky@yahoo.com

1 Yeshivah of Flatbush, Brooklyn, NY, USA

2 Maimonides Medical Center, Brooklyn, NY, USA woman is Jewish and the other is not, rabbinic authorities disagree about the halakhic Jewish status of the child, potentially making him or her impossible to marry in large segments of the traditional Jewish community. Recently, for example, a State Rabbinic Court in Beer-Sheva, Israel [3] refused to accept the Jewish status of a child carried and birthed by a Jewish woman until it had been satisfied that the egg donor was Jewish. Health providers working with infertile couples who insist on a Jewish surrogate or egg donor should be aware of the specific type of recordkeeping that a rabbinic court would require. [4]

Because the Jewish status of the child is contested, current policy is to suggest that the child undergo religious conversion. [5] However, this is not a simple solution, as many Orthodox rabbinic courts will convert children only if the parents are halakhicly observant. In any event, concerned individuals should be properly counseled as to the current status of potential issues.

\section{References}

1. Deonandan R. Thoughts on the ethics of gestational surrogacy: perspectives from religions, Western liberalism, and comparisons with adoption. J Assist Reprod Genet. 2020;37:269-79. https://doi.org/ 10.1007/s10815-019-01647-y.

2. Wolowelsky JB, Grazi RV. Current Jewish perspectives on maternal identity. Gynecol Endocrinol. 2014;30(12):929-30. https://doi.org/ 10.3109/09513590.2014.950644.

3. District State Rabbinic Court in Beer-Sheva, Israel. File 121693/1 (On the proper way to determine the Jewish status of a donated egg), (Hebrew) 2019 October 28.

4. Grazi RV, Wolowelsky JB. Addressing the particular recordkeeping needs of infertile Orthodox Jewish couples considering the use of donated eggs. J Assist Reprod Genet. 2014;31(3):251-3. https://doi. org/10.1007/s10815-014-0175-6.

5. Sherman A. Yihusim shel noladim me-hafraya hutz gufanit mitoremet zara (Hebrew). Yeshurin. 2009;21(5769):531-45.

Publisher's note Springer Nature remains neutral with regard to jurisdictional claims in published maps and institutional affiliations. 